\title{
POTRET KEHIDUPAN EKONOMI PEKERJA WANITA PADA PABRIK ROKOK DALAM KAJIAN GENDER
}

\author{
Mahyaya Fuaida ${ }^{1}$ \\ Diterima 8 November 2017, Dipublikasikan 17 April 2018 \\ CPenulis (2018)
}

\begin{abstract}
In the current era most women play a role in building the family economy. Women help husbands to earn income to sustain family economic life. Not only take care of households, women are also good at working outdoors. Even today many women prefer a career and put aside the household affairs. But in Indonesia there are still many women who are discriminated against in terms of employment, women are made up of second-class citizens and placed in the lowest job positions. The cigarette factory is a factory where most of its employees are women. Most of the women who work in cigarette factories make the job as the main livelihood in the family. Female workers in cigarette factories are placed in production for grinding and packing, the part being the lowest in the job classification in cigarette factories. In this context gender equality means that all human beings are free to develop their personal abilities and choose without being constrained by stereotypes and prejudices about gender roles or characteristics of men and women. Women also have the right to get a good livelihood. Gender equality does not mean that men and women are equal, or have become the same, but rights, responsibilities, social status and access to resources are independent of gender. Through this research, researchers want to reveal in more depth how the life of female workers in cigarette factory. This study used a qualitative approach to the type of phenomenal research, by interviewing several female workers selected through snowball techniques. This research is located in Sorgum cigarette factory of Malang regency. The results showed that female workers at the Sorgum Malang cigarette factory have not reached a good economy despite working for decades.
\end{abstract}

\section{Keywords}

Female Worker, Factory, Economy, Gender

\section{PENDAHULUAN}

Wanita sebagai salah satu anggota keluarga, seperti juga anggota keluarga yang lain mempunyai tugas dan fungsi untuk mendukung dalam berkeluarga. Pada era saat ini sebagian besar wanita ikut berperan dalam membangun ekonomi keluarga. Wanita membantu suami untuk mendapatkan penghasilan demi menopang kehidupan ekonomi keluarga. Tidak hanya mengurus rumah tangga saja, wanita juga pandai dalam bekerja di luar rumah. Bahkan saat ini banyak wanita lebih memilih berkarir dan mengesampingkan urusan rumah tangga.

Di zaman serba modern dan pembangunan saat ini, terjadi perubahan di seluruh bidang, di antaranya pendidikan, ekonomi, politik, sosial dan budaya. Meskipun demikian perubahan tersebut belum mampu membawa perubahan bagi wanita dalam dunia kerja. Sering kali perempuan masih dianggap sebagai individu yang bertanggung jawab akan kondisi rumah tangga dengan pekerjaan domestik tanpa harus terlibat dalam pekerjaan publik. Wanita sering diposisikan pada peran domestik dalam rumah tangga (Purnomo. 2015). Wanita dengan

\footnotetext{
1 Program Pasca Sarjana Pendidikan Ekonomi, Universitas Negeri Malang mahyayafuaida93@gmail.com
}

Jurnal Teori dan Praksis Pembelajaran IPS Volume 3, No.1, 2018, 48-52 ISSN 2503-5307 
keahlian rendah akan ditempatkan pada bagian pekerjaan yang rendah dan terkadang diperlakukan semena-mena.

Latar belakang pendidikan menjadi salah satu faktor yang sangat penting dalam memperoleh pekerjaan. Perempuan yang mempunyai pendidikan rendah sering kali wanita dianggap remeh dan ditempatkan dalam posisi kelas dua atau paling rendah di dunia kerja. Kondisi demikian telah dianggap sebagai hal yang lumrah karena dalam budaya Jawa, wanita telah lama dikonstruksikan secara sosial maupun budaya untuk menjadi "kanca wingking" (Wanita dikonstruksikan hanya berkutat pada berbagai urusan rumah tangga dan geraknya pun dibatasi dalam lingkup rumah tangga) (Nugraheni S, 2012).

Pekerja perempuan yang bekerja pada sektor industri sangat banyak di Indonesia Pabrik rokok merupakan salah satu pabrik yang menjadikan perempuan sebagai dominasi pada pekerjanya (Prianto Budly dan Mardiyono. 2016). Perempuan ditempatkan sebagai buruh di bagian produksi yang tidak banyak membutuhkan keterampilan khusus. Mereka hanya dibekali pelatihan dasar yang diperoleh dari pabrik. Pekerja pabrik rokok pada bagian produksi dibagi menjadi 2 yaitu bagian penggilingan dan pengepakan.

Pada artikel ini penulis melakukan penelitian pada salah satu pabrik yang berada di kabupaten Malang yaitu pabrik rokok Sorgum di Kabupaten Malang. Peneliti melakukan penelitian dengan cara observasi dan wawancara pada beberapa pekerja pabrik untuk mendapatkan informasi mengenai kehidupan pekerja wanita di pabrik Rokok.

\section{METODE}

Jenis penelitian ini adalah penelitian kualitatif dengan pendekatan Fenomenologi. Dengan meneliti fenomena kehidupan pekerja wanita pabrik rokok. Lokasi penelitian ini bertempat di pabrik rokok Sorgum kabupaten Malang. Dalam melaksanakan penelitian ini, pengumpulan data berasal dari informasi-informasi melalui partisipan yang disajikan secara deskriptif dan tidak memerlukan analisa perhitungan (Miles, M.B., \& Huberman, A.M. 1992). Penelitian ini ditujukan untuk memahami fenomena sosial dari sudut atau perspektif partisipan.

Dalam penelitian ini, peneliti melihat potret kehidupan pekerja wanita, melihat perilaku pekerja tersebut dalam kesehariannya, kemudian melakukan wawancara secara mendalam guna memperoleh informasi lebih detail. Pemahaman diperoleh melalui analisis berbagai keterkaitan dari partisipan, dan melalui penguraian "pemaknaan partisipan" tentang situasi-situasi dan peristiwa-peristiwa. Dari hal ini peneliti harus lebih menggali informasi yang dalam dari mahasiswa yang diteliti, dengan semua penjabaran kalimat yang keluar dari informan, peneliti harus mengetahui makna terucap dari informan dan merasakan peristiwa yang terjadi. Di sini peneliti merupakan mahasiswa jurusan ekonomi pembangunan yang bisa ikut berpartisipasi langsung dengan informan (Charles Teddlie and Fen Yu. 2007).

\section{HASIL DAN PEMBAHASAN}

Dari hasil observasi pada lokasi penelitian dan wawancara langsung pada informan, peneliti mendapati bahwa wanita yang dipekerjakan di pabrik ini sebagian besar berasal dari sekitar daerah-daerah sekitar lokasi pabrik dan rata-rata pekerja wanita tersebut sudah bekerja lebih dari 10 tahun. Pekerja di pabrik ini ada 2 macam yaitu pekerja tetap dan pekerja kontrak. Pekerja tetap di pabrik rokok Sorgum ini adalah pekerja yang sudah bekerja lebih dari 10 tahun dan mereka mendapatkan perlindungan dari JAMSOSTEK, sedangkan pekerja kontrak tidak terdaftar dalam jaminan tersebut dan bisa keluar dari pabrik kapan saja.

Pekerja wanita di pabrik ini sebagian besar adalah lulusan sekolah dasar yang minim keahlian dan pengalaman. Mereka sudah bekerja sejak masih usia dini dan bertahan bekerja hingga belasan tahun. Tidak adanya keahlian membuat pekerja wanita tidak mempunyai pilihan lain selain bekerja sebagai buruh pabrik tersebut.

Belasan tahun dijalani oleh pekerja wanita pabrik rokok Sorgum demi mencukupi kebutuhan sehari-hari. Dahulu mereka bekerja dari pagi sampai petang, bekerja menggiling dan mengepak 
batang-batang rokok untuk memenuhi target produksi. Namun semenjak 5 tahun terakhir kondisi pabrik Sorgum mengalami penurunan produksi, hal tersebut membuat para pekerja pabrik pulang lebih awal dan tentunya mengalami penurunan gaji yang diperoleh.

Semenjak kondisi tersebut yang dulunya karyawan pabrik berjumlah 1000 lebih kini hanya sekitar kurang lebih 300 orang. Mereka yang berstatus sebagai pekerja tetap memilih bertahan karena menunggu uang pesangon jika di terkena PHK dan juga karena tidak ada pilihan pekerjaan lain. Meskipun hanya mendapatkan upah yang sedikit pekerja wanita yang bertahan di pabrik Sorgum mengatakan bahwa upah tersebut lumayan sebagai penghasilan tambahan meskipun masih banyak kekurangan.

Sebagian besar wanita yang bekerja di pabrik rokok menjadikan pekerjaan tersebut sebagai mata pencaharian utama dalam keluarga. Belasan tahun mereka bekerja sebagai buruh pabrik demi kelangsungan hidupnya. Tak ada keahlian khusus yang bisa dilakukan, hanya berbekal pelatihan yang diberikan dari pihak pabrik, mereka bisa menjadi penopang kegiatan produksi pabrik rokok.

Selama bertahun-tahun pekerja wanita pabrik rokok bertahan, bekerja dari pagi hari hingga petang. Batang per batang rokok dihasilkan dari tangan-tangan wanita yang cekatan dalam menggiling dan mengepak rokok. Wanita-wanita tangguh yang bekerja keras tak kenal lelah demi membantu perekonomian keluarganya. Menggantungkan hidup dari banyaknya batang rokok yang akan diproduksi.

Pekerja wanita dipabrik Sorgum Malang mengungkapkan bahwa gaji yang diperoleh dari bekerja di pabrik belum cukup untuk memenuhi kebutuhan hidup, seperti yang diungkapkan beberapa pekerja wanita berikut ini, yang yaitu Ibu Titis yang bekerja di bagian produksi penggilingan berikut ini.

"Saya saat hanya bekerja 2 jam, dari jam 6 sampai jam 9, dengan pendapatan 19 ribu per harinya, uang tersebut tidak cukup untuk kebutuhan saya dan keluarga sehari-hari, maka dari itu saya berjualan sayur di dekat pabrik untuk mencari penghasilan tambahan" (wawancara tanggal 17 Juli 2017).

Dari keterangan Ibu Titis tersebut dapat disimpulkan bahwa informan tersebut mengalami kesulitan dalam pemenuhan kebutuhan sehari-hari karena gaji yang diterima sedikit.

Hal yang relevan diungkapkan oleh Ibu Khusnul berikut ini, Ibu Khusnul harus bekerja berjualan mie ayam setelah bekerja di pabrik, karena gaji yang diperoleh dari bekerja di pabrik belum cukup.

"Sejak keadaan pabrik mengalami penurunan produksi, gaji saya menurun drastis, yang dulunya saya masih bisa menyisakan gaji saya untuk menabung, saat ini tidak bisa sama sekali. Saya harus berjualan mie ayam sepulang bekerja di pabrik, lumayan untuk penghasilan tambahan. Saat ini nasib saya juga tidak jelas bagaimana, keadaan pabrik menurun seperti ini, saya menunggu di PHK saja, tidak tahu uang pesangon saya dibayarkan atau tidak." (wawancara tanggal 20 Juli 2017)

Dari keterangan tersebut dapat disimpulkan bahwa informan mendapatkan gaji yang sedikit dari bekerja di pabrik dan harus bekerja dibidang lain untuk mencari penghasilan tambahan. Informan tersebut juga mengaku tidak mendapatkan kejelasan pada pekerjaannya apakah akan mendapatkan pesangon atau tidak jika nanti terkena PHK.

Keterangan yang serupa juga didapatkan dari Ibu Mining yang bekerja lebih dari 12 tahun di pabrik rokok Sorgum seperti berikut.

"Kebutuhan sehari-hari kalau mengandalkan dari hasil bekerja di pabrik ya tidak cukup, sehari upah saya saja cuma 15 ribuan, itu mungkin hanya cukup untuk belanja sayuran saja sehari. Suami saya untungnya bekerja jadi kalau tidak cukup, ya dikasih sama suami. Kalau dulu sebelum keadaan pabrik begini ya lumayan gajinya meskipun harus bekerja seharian dengan upah sebulan sekitar 800-900 ribuan saja, tapi masih mending dari pada sekarang yang hanya 400 ribuan tiap bulan." (wawancara tanggal 20 Juli 2017).

Dari keterangan informan tersebut dapat disimpulkan bahwa gaji yang diperoleh di pabrik sorgum sedikit dan tidak dapat mencukupi kebutuhan hidupnya. 
Hasil wawancara yang dilakukan pada informan pada umumnya mengungkapkan bahwa gaji yang diperoleh dari bekerja sebagai buruh pabrik rokok Sorgum sangat sedikit dan belum cukup untuk memenuhi kebutuhan hidup. Sebagian dari pekerja wanita tersebut memilih untuk mencari pekerjaan lain untuk memperoleh penghasilan tambahan, sedangkan yang lainnya hanya pasrah saja karena tidak mempunyai keahlian lain selain bekerja sebagai buruh pabrik.

Observasi dan pengamatan langsung dilakukan oleh peneliti guna menyempurnakan data pada penelitian. Aktivitas pekerja wanita hanya pada saat jam 6 pagi sampai sekitar jam 9 pagi saja, setelah itu pekerja wanita pulang. Keadaan pabrik saat ini sedang surut, produktivitas menurun. Keterangan yang didapatkan peneliti keadaan tersebut berlangsung kurang lebih 5 tahun terakhir.

Keadaan pabrik yang tidak menentu tersebut membuat status pekerja wanita yang bekerja juga tidak jelas. Apakah pekerja wanita akan di PHK atau tidak dan masa kerjanya juga tidak jelas. Alasan sebagian besar pekerja wanita tetap bertahan di pabrik tersebut adalah menunggu uang pesangon yang jumlahnya cukup besar.

Puluhan tahun pekerja wanita yang bekerja di pabrik rokok Sorgum belum sejahtera. Tidak ada pilihan lain, tidak ada keahlian lain, demi kelangsungan hidup pekerja wanita di pabrik rokok Sorgum akan tetap mempertahankan pekerjaan tersebut. Saat ini pekerja wanita pabrik rokok Sorgum terancam terkena PHK, tidak ada jaminan pekerjaan lain setelah terkena PHK.

Kesetaraan gender, atau kesetaraan antara laki-laki dan perempuan, mengacu pada pemenuhan hak-hak, kesempatan dan perlakuan yang adil oleh laki-laki dan perempuan dari semua kelompok umur di segala tahapan kehidupan dan pekerjaan. Budaya bangsa Indonesia masih menanggap pekerja perempuan dianggap warga kelas 2 (dua) (Crawford, M and Unger, R. 2000). Saat ini masih banyak sekali pekerja wanita yang belum mendapatkan penghidupan yang layak dan hak sebagai mestinya.

Dalam Undang-Undang Republik Indonesia Nomor 13 Tahun 2003 Tentang Ketenagakerjaan tercantum untuk tidak adanya diskriminasi kerja, Pasal 5 "Setiap tenaga kerja memiliki kesempatan yang sama tanpa diskriminasi untuk memperoleh pekerjaan" maka Undang-Undang No.13 tahun 2003 menunjukkan komitmennya untuk menyediakan kesetaraan dalam kesempatan bekerja dengan tanpa diskriminasi baik itu laki-laki maupun perempuan. Kesempatan kerja pastinya harus ada di semua aspek politik, ekonomi dan sosial.

Kesetaraan gender menurut Inpres Nomor 9 Tahun 2000 meliputi persamaan hak untuk berperan dan berpartisipasi dalam kegiatan politik, ekonomi, sosial, budaya, pertahanan dan keamanan nasional, dan kesamaan dalam menikmati hasil pembangunan. Dalam melakukan kegiatan ekonomi pekerja wanita dan pria mempunyai kesempatan yang sama untuk memperoleh jabatan, serta tidak adanya diskriminasi untuk jenis pekerjaan yang sama.

Persamaan upah dan penempatan tenaga kerja terkait dengan gender merupakan dua hal yang perlu untuk dibahas, karena dalam fenomena yang terjadi kedua hal tersebut belum sepenuhnya dilaksanakan oleh perusahaan-perusahaan.

Fenomena yang terungkap seperti yang terjadi di pabrik rokok Sorgum antara lain adalah upah di bawah UMR, penempatan tenaga kerja, dan juga tidak ada jaminan atas perlindungan hak reproduksinya. Untuk mewujudkan kesetaraan gender tentunya tidaklah mudah, penulis berasumsi bahwa tidak terwujudnya kesetaraan gender terjadi karena masih adanya pandangan stereotip, marginalisasi wanita, dan sub ordinasi pandangan pekerja pria lebih tinggi dari pekerja wanita serta tidak adanya sanksi hukum kesenjangan gender dalam undang-undang ketenagakerjaan.

\section{SIMPULAN}

Pekerja wanita pabrik rokok sebagian besar menggantungkan hidupnya dari upah yang diperoleh dari bekerja sebagai buruk pabrik. Masih ada ditemukan pekerja wanita yang belum mendapatkan penghidupan yang layak, dan diskriminasi. Pabrik rokok merupakan pabrik yang sebagian besar pekerjanya adalah kaum wanita, pekerja wanita tersebut ditempatkan pada 
bagian terendah pada pabrik yakni bagian produksi penggilingan dan pengepakan. Pada penelitian yang mengambil lokasi di pabrik rokok Sorgum kabupaten Malang ini, menyimpulkan bahwa pekerja wanita yang bekerja di rokok tersebut belum sejahtera, gaji yang diperoleh jauh sekali dari UMR, bahkan sekarang keadaan pabrik yang surut membuat gaji yang pekerja wanita tersebut sangat minim. Keadaan pabrik yang surut dan pendapatannya menurun juga membuat keadaan pekerja semakin tidak jelas apakah akan terkena PHK dalam waktu dekat atau tidak, dan apakah pesangon akan dibayarkan atau tidak.

Demi mewujudkan kesetaraan gender dan pemerataan untuk penghidupan yang layak bagi pekerja tidaklah mudah, pemerintah harus berperan dengan memberikan sanksi hukum yang melanggar kesenjangan gender dalam undang-undang ketenagakerjaan. Kesetaraan gender berarti bahwa semua manusia bebas mengembangkan kemampuan pribadi mereka dan memilih tanpa dibatasi oleh stereotip dan prasangka tentang peran gender atau karakteristik lak-laki dan perempuan. Kesetaraan gender juga berarti

\section{DAFTAR PUSTAKA}

Adisu, Editus. 2006. Hak-hak Pekerja Perempuan. Tangerang: Visimedia

Charles Teddlie and Fen Yu. 2007. Mixed Methods Sampling: A Typology With Examples. Journal of Mixed Methods Research. Vol 1 No 1.p 77-100

Crawford, M and Unger, R. 2000. Women and Gender. McGraw Hill: New York

Miles, M.B., \& Huberman, A.M. 1992. Qualitative Data Analysis: an Expanded Source Book. Thousant Oaks CA: Sage Publication Inc.

Nugraheni S, Wahyu. 2012. Peran dan Potensi Wanita dalam Pemenuhan Kebutuhan Ekonomi Keluarga Nelayan. Journal of Educational Sosial Studies (JESS) Vol. 1, No. 2: 104-111

Purnomo, A. 2015. Study of Gender in Adaptation Strategies Post Kelud Volcano Eruption 2014. 1st UPI International Conference on Sociology Education (UPI ICSE 2015).

Prianto Budly dan Mardiyono. 2016. Potret Perempuan Buruh Perusahaan Rokok Di Kota Malang: Diantara Peran Domestik, Peran Produktif Dan Peran Publik. (online) http://lppm.trunojoyo.ac.id/budayamadura/wp-content/uploads/2016/10/2-19.ARTIKEL.pdf

Undang-Undang Republik Indonesia Nomor 13 Tahun 2003 Tentang Ketenagakerjaan. (online) www.kemenperin.go.id/kompetensi/UU_13_2003. diakses pada 27 September 2017. 